Wieś i Rolnictwo 4 (177)/2017

ISSN 0137-1673

doi: 10.7366/wir042017/01

\title{
Wspomnienie o Profesorze Zbigniewie Tadeuszu Wierzbickim (1919-2017)
}

\author{
Professor Zbigniew Tadeusz Wierzbicki (1919-2017) in Memoriam
}

Śmierć Profesora Zbigniewa Tadeusza Wierzbickiego okryła żałobą polskich (i nie tylko) socjologów wsi. Pożegnaliśmy ostatniego wybitnego przedstawiciela ich drugiej generacji ${ }^{1}$, uwikłanej w związki ideowe i naukowe „z ojcami założycielami” dyscypliny: Franciszkiem Bujakiem (1875-1953), Władysławem Grabskim (1874-1937), Ludwikiem Krzywickim (1859-1941), a także Florianem Znanieckim (1882-1958). Moje wspomnienie - przedstawiciela trzeciej generacji, a więc grupy socjologów wsi, urodzonych i ukształtowanych już po II wojnie światowej - ma charakter osobisty. Próbuję pokazać Profesora takim, jakim zanotowała ułomna i ulotna pamięć, w związku z czym szkicowany obraz jest nie tylko subiektywny, ale także pełen dziur i pominięć. Zawiedzionych, oczekujących opracowania bardziej uporządkowanego i faktograficznego ${ }^{2}$, odsyłam do tekstów o Zbigniewie Tadeuszu

1 Oprócz Z.T. Wierzbickiego zaliczam do niej również: Józefa Chałasińskiego (1904-1979), Kazimierza Dobrowolskiego (1894-1987), Dyzmę Gałaja (1916-2000), Bogusława Gałęskiego (1921-2010), Jana Turowskiego (1917-2006), a w jakimś sensie również Jana Szczepańskiego (1913-2004); urodzonych w okresie II Rzeczypospolitej, ukształtowanych na tradycjach tzw. złotego okresu polskiej socjologii wsi (1918-1939).

2 Niżej kilka podstawowych danych biograficznych, pochodzących z wymienionych w przypisie 3 opracowań Włodzimierza Wincławskiego. Zbigniew Tadeusz Wierzbicki urodził się 13 marca 1919 r. w Warszawie. W 1937 r. rozpoczął studia prawnicze na Uniwersytecie w Poznaniu, przerwane wojną. Dokończył je zaraz po wojnie, w warszawskiej Wyższej Szkole Handlowej. W 1949 r. doktoryzował się na Uniwersytecie w Poznaniu, po czym otrzymał stanowisko asystenta w Wyższej Szkole Handlowej w Warszawie, z której usunięto go z przyczyn politycznych. Po kilka latach utrzymywania się z prac dorywczych, na fali tzw. przemian popaździernikowych, w 1957 r. został zatrudniony w Instytucie Filozofii i Socjologii Polskiej Akademii Nauk w Warszawie. Pracował tam do 1980 r., habilitując się w roku 1963, a dziesięć lat później (1973) otrzymując tytuł profesora. W 1981 r. przeszedł na Uniwersytet Mikołaja Kopernika w Toruniu, fundamentalnie wzmacniając formujący się tam ośrodek socjologiczny, specjalizujący się w socjologii wsi. W 1989 r. przeszedł na emeryturę, kontynuując jednakże jeszcze bez mała przez lat trzydzieści intensywną działalność naukową i społeczną. Zakończył życie 7 czerwca 2017 r. 
Wierzbickim, które się już ukazały lub dopiero się pojawią w kraju i za granicą; przypominając, że Profesor czeka na biografię z prawdziwego zdarzenia ${ }^{4}$.

Z Profesorem Zbigniewem Tadeuszem Wierzbickiem zetknąłem się po raz pierwszy późno, zapewne dopiero u samego schyłku lat 70., w trakcie mojej asystentury w Zakładzie Socjologii Instytutu Nauk Społecznych Uniwersytetu Mikołaja Kopernika. Niezwykle szczęśliwym dla mnie zrządzeniem losu w kręgu toruńskich socjologów ${ }^{5}$ zaczęła się wtedy materializować idea powołania studiów socjologicznych i to w bardzo konkretnej specjalizacji, a mianowicie socjologii wsi. Ów pomysł, dość obrazoburczy jak na owe czasy ${ }^{6}$, wiązał się także (chociaż nie tylko) z osobą Zbigniewa Wierzbickiego. Nazwisko nie było mi obce, ale kojarzyło się głównie $\mathrm{z}$ autorem książki ${ }^{7}$, którą miałem obowiązek przestudiować jako student Uniwersytetu Gdańskiego, uczestnik seminarium magisterskiego prof. Romany Miller, pracującego nad przemianami wiejskich środowisk wychowawczych. Z konkretnym człowiekiem - dystyngowanym, ujmującym w tzw. obejściu, panem profesorem z Warszawy, a do tego czołowym polskim socjologiem wsi, rozpoznawanym

3 Odsyłam przede wszystkim do opracowań Włodzimierza Wincławskiego: Życiorys naukowy i twórczość Profesora Zbigniewa T. Wierzbickiego, w: Studia z socjologii wsi. Dedykowane Profesorowi Zbigniewowi Wierzbickiemu, red. W. Wincławski, Toruń 1993; Zbigniew Tadeusz Wierzbicki, The Master of Polish Rural Sociology, „Eastern European Countryside” 2009, nr 15; Zbigniew Tadeusz Wierzbicki. Nestor polskiej socjologii wsi, w: Cztery dekady socjologii na Uniwersytecie Mikołaja Kopernika. Socjologia i socjologowie wsi krajów Europy Środkowej, red. A. Kaleta, Toruń 2012. Wspomnienie o Profesorze opublikował już anglojęzyczny „Eastern European Countryside” (23/2017), a na początku 2018 r. opublikuje niemieckojęzyczny „Land Berichte” (1/2018). Wiele ciekawych informacji o Profesorze Wierzbickim piór: Jacka Giebułtowicza, Andrzeja W. Kaczorowskiego, Zofii Nakielskiej-Cremers i Jana Turnaua publikuje również kwartalnik „Bunt Młodych Duchem” (3/2017).

4 Zainteresowanych przygotowaniem biografii Zbigniewa Tadeusza Wierzbickiego zapraszamy do Instytutu Socjologii Uniwersytetu Mikołaja Kopernika, który jest dysponentem Jego bogatej spuścizny naukowej, pod postacią biblioteki i archiwum osobistego.

5 Zgromadzonych głównie wokół toruńskiej Stacji Naukowo-Badawczej Instytutu Rozwoju Wsi i Rolnictwa Polskiej Akademii Nauk (powstałej w 1972 r.), kierowanej przez ówczesnego docenta Zbigniewa Kwiecińskiego, który zainicjował działania na rzecz uruchomienia Zakładu Socjologii na Uniwersytecie Mikołaja Kopernika.

6 Od początku lat 60. starano się ograniczać rozwój socjologii akademickiej, której - szczególnie po wydarzeniach marcowych roku 1968 - ówczesne władze przypisywały tendencje rewizjonistyczne. W jeszcze większym stopniu owa niechęć dotyczyła socjologii wsi, ze względu na jej tradycyjne związki z rodzinnym gospodarstwem rolnym i chłopską wsią, z gruntu obcymi obowiązującej doktrynie socjalistycznej industrializacji rolnictwa i modernizacji wsi.

7 Jak łatwo się domyśleć, chodzi o książkę napisaną wspólnie z Alvinem L. Bertrandem, zatytułowaną Socjologia wsi w Stanach Zjednoczonych: Stan i tendencje rozwojowe (Ossolineum, Wrocław-WarszawaKraków 1970). 
w kraju i za granicą ${ }^{8}$ - nawiązałem pierwsze relacje (wpierw o charakterze bardziej służbowym niż osobistym ${ }^{9}$ ), kiedy Ten od czasu do czasu, u progu wielkiej zmiany systemowej, zaczął bywać w niewielkim pokoiku toruńskiego Zakładu Socjologii. Jego ówczesny szef, wtedy docent Włodzimierz Wincławski, zwracał się do Niego per Zbyszku i darzył czymś więcej niż szacunkiem. Ich relacje już wtedy przypominały więź ojca i syna, pozostając zresztą takimi do ostatnich dni życia Profesora. Ten szczególny związek wpierw doktoranta ${ }^{10}$, a potem współpracownika i przyjaciela, ze swoim profesorem i mentorem był zapewne nie najważniejszą, ale godną uwagi, przesłanką działań mających na celu powołanie na UMK ośrodka socjologii wsi. Ich konkretyzacji, zaraz na początku lat 80., sprzyjała i druga okoliczność, znowu bezpośrednio związana z Zbigniewem Wierzbickim. Ten bowiem odegrał znaczącą rolę w organizacji IV Światowego Kongresu Socjologii Wsi, obradującego w Toruniu od 9 do 13 sierpnia $1976 \mathrm{r}^{11}$, a to wydarzenie, jak napisze po blisko 30 latach Włodzimierz Wincławski: „[... ] niewątpliwie stanowiło ważny impuls dla późniejszego bujnego rozwoju tej subdyscypliny w ramach socjologii toruńskiej. [...] Pragnąc umocnić pozycję Zakładu, powołano w 1982 r. Podyplomowe Studium Socjologii Wsi (początkowo roczne, od 1984 dwuletnie), kształcące słuchaczy z wyższym wykształceniem niesocjologicznym, związanych profesjonalnie ze wsią i rolnictwem. W Studium tym podjął wykłady zlecone profesor Zbigniew Tadeusz

8 Zbigniew Tadeusz Wierzbicki był zapraszany z wykładami i odczytami przez uniwersytety w wielu krajach, w tym wielokrotnie przez amerykańskie i francuskie. Aktywności naukowej za granicą sprzyjała dobra znajomość trzech języków obcych: angielskiego, niemieckiego, a przede wszystkim francuskiego. Niewątpliwie był admiratorem kultury francuskiej i znakomitym znawcą francuskiej socjologii wsi, którą przybliżył polskim socjologom w przygotowanej i zredagowanej razem ze swoim przyjacielem, profesorem Placide Rambaud, książce zatytułowanej Socjologia wsi we Francji (Toruń 1994). Nie ma nadmiernej przesady w stwierdzeniu, że Jemu przede wszystkim polska socjologia wsi zawdzięczała w latach 60. i 70. wypłynięcie na szerokie międzynarodowe wody, po okresie stalinowskiego „zamrożenia”. Do tych zasług nawiązał prof. dr. hab. Krzysztof Gorlach, żegnający Profesora w imieniu polskich socjologów wsi na Starych Powązkach (20 czerwca 2017). Trawestując słowa Roberta K. Mertona o współczesnych socjologach „stojących na ramionach olbrzymów” (Karola Marksa, Maxa Webera, Floriana Znanieckiego i innych) przypisał Wierzbickiemu rolę jednego z takich „olbrzymów polskiej socjologii wsi”, dzięki któremu my - stojący na Jego ramionach - widzimy dużo dalej i lepiej.

9 Bardziej osobiste ograniczały się wtedy przede wszystkim do tego, że jako posiadacz samochodu miałem zaszczyt i przywilej przywożenia i odwożenia Profesora na dworzec PKP.

10 Włodzimierz Wincławski był pierwszym doktorem wypromowanym przez Profesora, z którym, aż do jego śmierci, utrzymywał ścisłe kontakty zawodowe i osobiste. Zbigniew Wierzbicki dał temu wyraz w momentami wzruszającym opracowaniu, które przygotował z okazji jubileuszu 70-lecia swego najwybitniejszego wychowanka. Zob. Z.T. Wierzbicki, Profesor Włodzimierz Wincławski, w: Cztery dekady socjologii na Uniwersytecie Mikołaja Kopernika.

11 Więcej na temat kulis i przygotowań do organizacji pierwszego międzynarodowego kongresu socjologów wsi w kraju za tzw. żelazną kurtyną - w tym udziału Profesora Wierzbickiego - w: H. Podedworna, Fortieth Anniversary of IV World Congress of Rural Sociology in Toruń, „Eastern European Countryside” 2016, nr 22. 
Wierzbicki z Instytutu Filozofii i Socjologii PAN, który w roku 1984 przeszedł do $\mathrm{UMK}^{\prime 12}$.

Ponieważ do 1991 r. miałem zaszczyt kierować rzeczoną jednostką organizacyjną, z natury rzeczy moje kontakty z Profesorem uległy znaczącej intensyfikacji, a konsultacje telefoniczne - Profesor mieszkał w Warszawie, a do Torunia przyjeżdżał kilka razy w semestrze - stały się prawie codziennością. Zbyszek (mniej więcej wtedy też uzyskałem pozwolenie zwracania się do Profesora po imieniu) stawał się dla mnie - socjologicznie rzecz ujmując - coraz ważniejszym znaczącym innym, i to nie tylko w sferze życia zawodowego, ale także prywatnego. Chociaż nasze blisko 40-letnie więzi, z początku koleżeńskie, stopniowo nabierały charakteru bardziej przyjacielskich, nie mogę twierdzić, że znałem Zbyszka bardzo dobrze. Z pewnością jednak poznałem na tyle, aby nie mieć żadnych wątpliwości, że los dał mi możliwość pozyskiwania wiedzy i doświadczenia życiowego od człowieka jedynego w swoim rodzaju: mądrego, prawego i szlachetnego, harmonijnie łączącego pracę naukową $\mathrm{z}$ aktywnością społeczną.

Jego osobowość ukształtowała nie tylko rodzina, zresztą o pięknych tradycjach patriotyczno-społecznikowskich, ale przede wszystkim gimnazjum w Rydzynie, do którego uczęszczał w latach 1932-1937 i nawiązywał przez całe życie, również w wystąpieniach publicznych ${ }^{13}$. Założyciela i dyrektora szkoły (Tadeusza Łopuszańskiego) uznawał za swego mentora, często odwołując się do jego idei pedagogicznych - świadczenia prawdy, rozwijania indywidualnych zainteresowań oraz zamiłowania do pracy twórczej ${ }^{14}$ - wyraźnie potem obecnych w działalności pro publico bono i pracy naukowej Profesora. Obie sfery aktywności łączyła zasada action and research, a więc uprawiania nauki $\mathrm{w}$ ścisłym związku $\mathrm{z}$ potrzebami praktyki społecznej, zgodna zresztą z duchem socjologii pozytywistycznej, z którą Zbyszek chyba najbardziej się identyfikował.

W latach 1980-1981 - a więc okresie „pierwszej Solidarności”, kiedy mogłem już osobiście obserwować Profesora „w działaniu i badaniu”15 - owa zasada naj-

12 W. Wincławski, Dzieje socjologii w Toruniu do końca wieku XX, w: Cztery dekady socjologii na Uniwersytecie Mikołaja Kopernika, s. 35-36.

13 Trwała więź Profesora Wierzbickiego ze swoją szkołą średnią znalazła wzruszające dopełnienie podczas jego pogrzebu. W ostatniej drodze do grobu rodzinnego na warszawskich Starych Powązkach towarzyszyły Profesorowi trzy poczty sztandarowe wystawione przez szkoły i drużyny harcerskie kultywujące tradycje rydzyńskiego gimnazjum.

14 R. Łętocha, O lepszq szkołe, pomyślność kraju i zdrowsze społeczeństwo. Tadeusz Łopuszański jako pedagog i wychowawca, https://nowyobywatel.pl/2014/01/27/o-lepsza-szkole-pomyslnosc-kraju-i-zdrowsze-spoleczenstwo-tadeusz-lopuszanski-jako-pedagog-i-wychowawca/ [dostęp: 07.09.2017].

15 Z tego co dość powszechnie wiadomo, Zbigniew Tadeusz Wierzbicki w działalność tego rodzaju angażował się już dużo, dużo wcześniej, już we wczesnej młodości. Jako dwudziestolatek, jesienią 1939 r., w okupowanym Nałęczowie wraz z matką zorganizował tajne nauczanie w zakresie szkoły średniej, wykładając 
pełniej materializowała się w Jego zaangażowaniu, wpierw w monitorowanie narodzin „Solidarności wiejskiej”, a potem we wspomaganiu tego ruchu społecznego przez dostarczanie wiedzy eksperckiej, występowanie „[... ] zarówno ze słowem mówionym, jak i pisanym, publikując teksty publicystyczne i felietony w gazetkach drugiego obiegu wydawniczego"16. Po stanie wojennym dalszym ciągiem tej działalności, w jakimś sensie rzecz jasna, była dydaktyka na Podyplomowym Studium Socjologii Wsi. W ramach wykładów z socjologii wsi, stosowanej socjologii wsi oraz teorii i praktyki spółdzielczości cierpliwie przekonywał swoich słuchaczy do inicjowania działań oddolnych, samoorganizacji na szczeblu lokalnym i brania spraw w swoje ręce tam, gdzie to tylko w ówczesnych warunkach było możliwe. Owe postulaty - dzisiaj powszechnie łączone $\mathrm{z}$ budową podstaw społeczeństwa obywatelskiego - były przy tym doskonale teoretycznie przemyślane i obudowane, jako że stanowiły praktyczną konsekwencję Jego zainteresowań naukowych, urzeczywistnianych w pracy badacza społeczeństwa, zatrudnionego od połowy lat 50. w Instytucie Filozofii i Socjologii Polskiej Akademii Nauk. Szczególne znaczenie, nie tylko jako teoretyczna podbudowa koncepcji podmiotowego rozwoju wsi, ale również dla rozwoju polskiej socjologii wsi całego okresu powojennego, miały liczne opracowania naukowe Wierzbickiego poświęcone aktywizacji społeczności lokalnych. Nawiązywał w nich, z jednej strony, do socjologicznych koncepcji ruchów spółdzielczych; $\mathrm{z}$ drugiej zaś do amerykańskiej teorii community development. Ich synteza - pod wieloma względami nowatorska, upowszechniana i wykładana w Polsce pod akronimem AiRSL (Aktywizacja i Rozwój Społeczności Lokalnych) - zawarta w sygnalizowanej wcześniej (zob. przypis nr 7) książce napisanej wspólnie z socjologiem amerykańskim Alvinem L. Bertrandem, w latach 90 . XX w. z całym dobrodziejstwem inwentarza została włączona do teoretycznego zaplecza ruchów odnowy wsi.

Być może jeszcze pełniejsze odzwierciedlenie reguła action and research znalazła w innej sferze działań społecznych i zainteresowań naukowych Profesora, a mianowicie związanych z szeroko pojętą ochroną środowiska przyrodniczego.

teorię spółdzielczości oraz historię Polski. Zaraz po zakończeniu wojny, w latach 1946-1947, pracował we wrocławskim oddziale Polskiego Związku Zachodniego, gdzie angażował się w obronę ludności autochtonicznej prześladowanej przez szabrowników, wielokrotnie narażając się na utratę życia. W mniej więcej tym samym okresie włączył się w reaktywowanie autentycznej spółdzielczości, a począwszy od 1956 r. angażował w społeczny ruch przeciwalkoholowy, stając się jednym z głównych jego organizatorów w Polsce. Jego osobistą zasługą było zainicjowanie ruchu Anonimowych Alkoholików, powołanie niezależnego miesięcznika „Trzeźwość”, konsekwentne propagowanie ruchu AA; „[...] metodycznie, w nieskończonej liczbie prelekcji przyswajając naszemu społeczeństwu zasady 12 kroków samopomocowego ruchu osób uzależnionych od alkoholu”. Cyt. za: J. Giebułtowicz, Profesor, który umiał słuchać, „Bunt Młodych Duchem” 1997, nr 3, s. 4.

16 A.W. Kaczorowski, Doradca rolników z „Solidarności”, „Bunt Młodych Duchem” 1997, nr 3, s. 7. Ten sam autor, w latach 1980-1981 reporter „Słowa Powszechnego”, twierdzi w swoim opracowaniu, że Profesor Wierzbicki należał do głównych doradców NSZZ RI „Solidarność”. 
Ich zwieńczeniem była ostatnia książka (Sozoekologia społeczna. Główne problemy / materiały / rozwiązania, Toruń-Warszawa 2008), napisana niejako "na wejściu” w dziewiątą i ostatnią dekadę życia ${ }^{17}$. Pracę nad socjologicznymi podstawami ochrony środowiska naturalnego, $\mathrm{z}$ tego co wiem, rozpoczął jeszcze w latach 70 . pod wpływem licznych doświadczeń $\mathrm{z}$ działań ruchów ekologicznych ${ }^{18}, \mathrm{z}$ zamiarem naszkicowania zarysu nowej dziedziny socjologii jako unowocześnionej wersji ekologii człowieka, syntetyzującej problematykę nie tylko ochrony dziedzictwa przyrodniczego, lecz także dziedzictwa kulturowego, części zasobów naturalnych naszej planety. Nazwał ją sozoekologią społeczną i włączał w poszukiwania nowego paradygmatu redefiniującego lub na nowo definiującego przedmiot socjologii wsi ${ }^{19}$, a więc dyscypliny naukowej, z którą się identyfikował od samego początku aktywności naukowej. Należy w tym miejscu przypomnieć, że do dorobku jej „złotego okresu" bezpośrednio nawiązywała Jego pierwsza książka (Żmiąca w pół wieku później - Warszawa 1963), ponowna monografia wsi opisanej po raz pierwszy w $1903 \mathrm{r}$.

17 W powstawaniu tej książki miałem zaszczyt uczestniczyć jako konsultant pewnych nowych rozwiązań edytorskich, gdyż właśnie Sozoekologia społeczna pióra Zbigniewa Tadeusza Wierzbickiego inaugurowała tworzenie zaplecza podręcznikowego dla innowacyjnego kierunku studiów Zrównoważony rozwój obszarów wiejskich. Stanowiła pracę pod wieloma względami pionierską, nie tylko dlatego, że mieliśmy do czynienia z pierwszym naukowym opracowaniem podstaw nowej socjologii szczegółowej, ale także w sensie edytorskim. Była bowiem przeznaczona dla studiujących zarówno w systemie tradycyjnym, jak i w systemie studiów na odległość (ang. distance learning). Do tych zróżnicowanych potrzeb dydaktyki akademickiej została dostosowana przez Profesora struktura książki, zawierającej trzy rodzaje tekstów: klasyczne rozdziały (10), poszerzenia (tzw. boxy - 16), studia przypadków (15). Całość zaopatrzono w słowniczek podstawowych pojęć, a sprawdzenie poziomu przyswojenia wiedzy umożliwiały pytania kontrolne proponowane na końcu każdego rozdziału.

18 Jeszcze w latach 60. uczestniczył w budowie jego struktur, powoływany jako ekspert ds. spraw społecznych aspektów ochrony środowiska przez instytucje administracji państwowej i ciała społeczne. Był członkiem Rady Naukowej Zarządu Głównego Ligi Ochrony Przyrody, a w latach 1977-1982 jej wiceprzewodniczącym. Po przełomie politycznym 1989 r. został członkiem Komisji Ochrony Środowiska przy Prezydencie RP.

19 Mówił o tym jako uczestnik dyskusji panelowej na międzynarodowej konferencji naukowej Nowe zadania socjologii wsi w procesie rozwoju obszarów wiejskich Europy (Toruń, 6 maja 2006): „Jak więc nazwać dyscyplinę, zajmującą się problemami (podejście statyczne) i przemianami (w ujęciu dynamicznym) na obszarach określanych nadal jako wieś? Wydaje się, że dyscyplina ta powinna: 1) obejmować całą ludność i to nie tylko na obszarach ściśle wiejsko-rolniczych, lecz również ludność nierolniczą mieszkającą nie tylko we wsi, lecz i w jej okolicy, a więc w małych miastach, miasteczkach, powiązaną interesami i więzami kulturowymi z ludnością rolniczą, która będzie stanowić nadal w nowej dyscyplinie centralny punkt odniesienia. Co więcej, dyscyplina ta pod nową, bardziej adekwatną nazwą, powinna włączyć w zakres swoich zainteresowań związki i relacje ludności z otoczeniem przyrodniczym w perspektywie amerykańskiej human ecology, z dodanym jednak koniecznie «współczynnikiem ochrony środowiska przyrodniczego», a więc sozoekologicznym punktem widzenia. Uwzględniając wymienione powyżej cechy, wydaje się, iż nazwa nowej dyscypliny mogłaby brzmieć: «socjologia wiejsko-małomiejskiego kontinuum» bądź «socjologia sozo-ekologicznego wiejsko-małomiejskiego kontinuum»" Z.T. Wierzbicki, wypowiedź nieautoryzowana, sporządzona na podstawie notatki autora. 
przez Franciszka Bujaka, pioniera polskich badań monograficznych. Opracowanie Wierzbickiego - na podstawie którego w 1963 r. uzyskał habilitację - przyczyniło się do wznowienia trwającego do dziś zainteresowania polskich socjologów wsi metodą monograficzną ${ }^{20}$. Działalność naukowa Profesora Wierzbickiego nie zamykała się bynajmniej w stosunkowo wąskich ramach socjologii wsi. W ok. 300 publikacjach sensu stricto naukowych ${ }^{21}$, a także w jeszcze większej liczbie wystąpień konferencyjnych, podejmował także wiele innych zagadnień, m.in.: trzeźwości i alkoholizmu, religijności i świadomości narodowej Polaków, a także dziejów socjologii.

Kolejną konsekwencją wyznawanego systemu wartości, przesiąkniętego duchem idei społecznych rydzyńskiego gimnazjum, była zgodność wypowiadanych słów, w tym także sądów naukowych, z czynami. Profesor płacił za to wysoką cenę w życiu zawodowym, a niekiedy i osobistym. Przykładem z tej pierwszej sfery niechaj będzie Jego wystąpienie w latach 70., kiedy „[...] podczas jednego $\mathrm{z}$ oficjalnych hucznych kongresów pod hasłem «walki o trzeźwość społeczeństwa» [...] ogłosił publicznie, że w Polsce bardzo jest trudno zwalczać pijaństwo, ponieważ jest ono immanentnie związane z panującym ustrojem politycznym"22, które kosztowało opóźnienie awansów naukowych, a także odcięcie od możliwości pracy dydaktycznej na polskich uczelniach wyższych. Jego udział w Radzie Konsultacyjnej przy gen. Jaruzelskim - zresztą za wiedzą i aprobatą Episkopatu - a także dość krytyczny stosunek do niektórych posunięć rządu Tadeusza Mazowieckiego (w tym przede wszystkim publiczna krytyka tzw. reform Balcerowicza, szczególnie tych związanych ze sposobem potraktowania własności państwowej i spółdzielczej w sektorze rolnym), kosztowała go Order Orła Białego. Wniosku złożonego w 2011 r. przez Radę Wydziału Humanistycznego i Senat Uniwersytetu Mikołaja Kopernika, wspieranego przez Ministra Nauki i Szkolnictwa Wyższego, nie poparła Kapituła Orderu, prawdopodobnie właśnie z tych dwóch powodów ${ }^{23}$. Do

20 Swojemu przywiązaniu do nurtu monograficznego dał ponownie szerszy wyraz w książce (napisanej już na emeryturze) poświęconej Dimitriemu Gustiemu, twórcy rumuńskiej szkoły badań monograficznych (Dimitrie Gusti. Socjolog niepodległej Rumunii, Toruń 1991). Zob. także: Z.T. Wierzbicki, Dimitrie Gusti and his school, „Eastern European Countryside” 1996, nr 2.

21 Nie znamy jeszcze ostatecznej liczby Jego publikacji, która oscyluje zapewne w okolicach pół tysiąca. W bibliografii obejmującej to, co napisał od 1945 do 1992 r., widnieje 370 prac opublikowanych oraz 40 niepublikowanych. Zob. M. Major, W. Wincławski, Bibliografia prac Profesora Zbigniewa T. Wierzbickiego za lata 1945-1992, w: Studia z socjologii wsi. Dedykowane Profesorowi Zbigniewowi Wierzbickiemu, red. W. Wincławski, Toruń 1993.

22 J. Giebułtowicz, Profesor, który umiat stuchać, s. 4.

${ }^{23}$ Gwoli sprawiedliwości dodajmy jednak, że zasługi Profesora Zbigniewa Wierzbickiego dla państwa i społeczeństwa polskiego zostały uhonorowane na wiele innych sposobów. W 2011 r. za wybitne zasługi w zakresie budowania społeczeństwa obywatelskiego otrzymał z rąk Prezydenta RP Krzyż Komandorski Orderu Odrodzenia Polski, który poprzedziły liczne wyróżnienia nadane przez różne instytucje prywatne (chyba dla Niego najcenniejsze) i państwowe. I tak (wskazuję nieliczne, moim zdaniem, najbardziej przez 
sfery bardziej osobistej odnosiły się chociażby docinki, a niekiedy i swego rodzaju ostracyzm, jaki spotykał Zbyszka ze strony niektórych przedstawicieli środowiska naukowego z powodu jego abstynencji i ostrej, publicznej krytyki, z jaką spotykał się alkohol serwowany podczas różnego rodzaju konferencji naukowych, a także innych spotkań tzw. oficjalnych. Z tego co wiem i osobiście mogłem zaobserwować, nigdy jednak słowa nagany nie były kierowane w stronę konkretnych osób, raczej zjawiska jako takiego.

Innym przejawem zgodności słów z czynami, teorii naukowej z praktyką społeczną, był swego rodzaju rygoryzm codzienności. $Z$ tych stosunkowo nielicznych (jak na prawie 40 lat znajomości) spotkań w okolicznościach bardziej nieformalnych - wspólne posiłki po zajęciach w Toruniu; kilka wspólnych wyjazdów zagranicznych; wizyt w Ciechocinku, gdzie chętnie wczasował, pracując; czy wreszcie kilku spotkań w Jego warszawskim mieszkaniu czy moim wiejskim domu - wynosiłem wrażenie, że Zbyszek stanowi prawie perfekcyjną ilustrację - w kategoriach weberowskiego typu idealnego - ekologicznego stylu życia, doskonale spuentowanego w wierszyku, który chętnie zresztą cytował na zajęciach:

Zdrowie oszczędzaj i czas,

Prąd $i$ wodę i gaz,

nerwy, watrobę i pluca,

Niczego nie wyrzucaj!

Z czegoś wyrosła - podłuz,

Co oszczędziłaś - odłóż,

Uczucia oszczędzaj cudze,

Sobie oszczędzaj złudzeń,

I tak z wszystkiego po trochu

oszczędzisz - nie na samochód

być może,

ale by życie pędzić miło i przyzwoicie $e^{24}$.

\footnotetext{
Zbyszka cenione): w 1947 r. otrzymał wyróżnienie Polskiego Związku Zachodniego za „pracę społeczną związaną z odbudową polskości odzyskanych Ziem Zachodnich", w latach 1977-1988 złote odznaki trzech stowarzyszeń pozarządowych oraz wyróżnienie Niezależnej Fundacji Popierania Kultury Polskiej „Polcul Foundation” w Australii, za „Zwalczanie patologii społecznej”, nagrody czterech województw (kieleckie, leszczyńskie, nowosądeckie i poznańskie) za zasługi dla ich rozwoju w zakresie aktywizacji społeczności lokalnych, w 1993 r. stowarzyszenie „Civitas Christana” przyznało mu Nagrodę im. W. Pietrzaka. Był również członkiem honorowym Unii Wielkopolan, Polskiego Klubu Ekologicznego i Polskiego Towarzystwa Psychiatrycznego.

24 Jego autorem jest prawdopodobnie Andrzej Nowicki, znany filozof i ekolog. Cytuję na podstawie notatki sporządzonej w trakcie jednego z wystąpień Profesora.
} 
Niemal do legendy urosła niechęć Zbyszka do notowania na czystych kartach papieru maszynowego, a później, w erze komputera, do drukarek. Robił notatki, pisał szkice wystąpień, dyspozycje do wykładów itp. na odwrotnych stronach papieru już zadrukowanego i przeznaczanego zazwyczaj na makulaturę. Dla wielu rzeczy, już wydawało się zbędnych, starał się znaleźć jeszcze nową funkcję użytkową, czego przykładem stare kartki pocztowe - przywiezione prawdopodobnie jako pamiątki z podróży odbywanych nierzadko jeszcze w latach 60 . - jakie, zapisane drobnym maczkiem, otrzymywałem jeszcze przed kilkunastu laty, a więc już w wieku XXI. Przejawem szczególnej troski o środowisko naturalne był pełen atencji stosunek do wszystkiego co żyje, w tym roślin i zwierząt, oraz sprzeciw wobec ich nierozumnego (bez absolutnej konieczności) niszczenia czy zabijania. Do dziś pamiętam jego autentyczne oburzenie, kiedy na jednym z seminariów poświęconym ochronie tożsamości kulturowej wsi zauważył, że grupa artystów do swej akcji performatywnej użyła wyciętych z lasu drzewek młodych brzóz. Ten rygoryzm nie miał nic wspólnego ze skąpstwem. Żył wprawdzie skromnie, nawet może niekiedy ascetycznie, kiedy chodziło o zaspokajanie potrzeb własnych, ale był (może nawet czasem przesadnie) hojny, kiedy chodziło o sprawy publiczne. Przykładem owej szczodrości był dwumiesięcznik „Bunt Młodych Duchem”25, który od $2001 \mathrm{r}$. redagował i wydawał własnym sumptem, przeznaczając na to nie tylko znaczą część swojej profesorskiej emerytury, ale także honoraria otrzymywane za wykłady w szkołach prywatnych, w których pracował, znacznie już przekroczywszy 80 rok życia. Te zresztą chętnie korzystały z Jego usług, gdyż przyciągał słuchaczy charyzmą nie tylko wybitnego uczonego dysponującego ogromną wiedzą, ale również praktyka społecznego, osobiście zaangażowanego w urzeczywistnianie głoszonych prawd.

A wykładowcą i mówcą zarazem był znakomitym, o czym mogłem się osobiście przekonać, słuchając Zbyszka po wielokroć, przede wszystkim jako referenta, a nade wszystko dyskutanta, wielu konferencji naukowych. Nie pamiętam, aby uczestnicząc w jakimś mniej czy bardziej ważnym spotkaniu, nie zabierał głosu, zawsze w sposób przemyślany, precyzyjnie skonstruowany, kraszony celnie dobieranymi przykładami czerpanymi z długiego i bogatego życia, z jasnym przesłaniem i końcową konkluzją. Nie cierpiał gadulstwa, mówienia, co ślina na język przyniesie, w związku z czym zabierał głos, posługując się uprzednio sporządzoną notatką, bo uczestnictwo w spotkaniu niosło za sobą obowiązek nie tylko uważnego słuchania, ale również

25 Pismo przez Niego redagowane i finansowane przedstawiało wielostronny i maksymalnie obiektywny obraz różnych problemów nurtujących współczesne społeczeństwo polskie (z szczególnym naciskiem na sprawy rozwoju społeczeństwa obywatelskiego oraz ochrony dziedzictwa), prezentowanych w duchu poszanowania praw człowieka, dialogu społecznego, szczególnie z sąsiadującymi narodami i między różnymi religiami i światopoglądami. 
zanotowania, co mówią inni. Konkret i prostotę treści wykładów Profesora oraz gotowość do uważnego słuchania podkreśli również słuchacze Podyplomowego Studium Socjologii Wsi: „[...] prowadzone przez Profesora wykłady cieszyły się dużym zainteresowaniem, a ich wartość wzmacniał sposób narracji oraz wszystko to, co wynikało z połączenia takich cech Profesora jak wysoka kultura osobista, erudycja, rzetelność, nieustępliwość i zaciekawienie. Zachęcał wszystkich do dyskusji, podkreślając wagę pytań i umiejętności ich formułowania, które to uważał za punkt wyjścia dla naukowego poznania. Bez względu na poziom wypowiedzi słuchacza, jej merytoryczność, nie zdradzał zniecierpliwienia czy broń boże lekceważenia. Dumni byliśmy, gdy podtrzymywał z nami rozmowę: gorzej było, gdy milczał i w charakterystyczny dla siebie sposób przyglądał się zza okularów głoszącemu «prawdy objawione». Gdy ów kończył Profesor podsumowywał: «tak, to jest interesujące. Skąd Pani/Pan przyjechał/a?»"26.

Odszedł spokojnie w czerwcowe popołudnie, w zaciszu domowym, zasnąwszy w fotelu. Przeszedł w stan spoczynku, którego nie miał czasu doświadczyć w swoim pracowitym życiu.

Andrzej Kaleta

26 Fragment wspomnień dr hab. Krystyny Dziubackiej, słuchaczki Podyplomowego Studium Socjologii Wsi w latach 1988-1990. 